\title{
We the people, We the public space. An interactive exhibition at the 9th World Urban Forum
}

\author{
Luisa Bravo, Valerio Francia \\ City Space Architecture, Italy \\ luisa.bravo@cityspacearchitecture.org | valerio.francia@cityspacearchitecture.org
}

At the Ninth session of the World Urban Forum, convened by UN-Habitat, the United Nations Human Settlements Programme, held on 7-13 February 2018 in Kuala Lumpur, City Space Architecture was selected to be part of the event as an exhibitor: it was included in the exhibition area, held at the main venue of the Forum, the Kuala Lumpur Convention Centre, besides the Petronas Towers, as the only Italian exhibitor, together with 200 selected exhibitors from 50 countries.

City Space Architecture's exhibition space was curated by Luisa Bravo (Founding Member and President of City Space Architecture) in collaboration with Mirko Guaralda

(Queensland University of Technology, Australia), Hendrik Tieben (The Chinese University of Hong Kong, Hong Kong) and Manfredo Manfredini (University of Auckland, New Zealand), and with Winyu Ardrugsa and Jarunee Pimonsathean (UDDI Thammasat University, Thailand). The organizational manager of the exhibition space was Valerio Francia (Founding Member and Treasurer of City Space Architecture). City Space Architecture's exhibition space was intended to showcase City Space Architecture's international projects on public space for the implementation of the New Urban Agenda and to spread information about networking activities and ongoing campaign and events promoted by City Space Architecture, such as the global campaign "Stand up for Public Space!" (Bravo et al., 2017), launched at the Habitat III conference in Quito during a networking event.

The exhibition space hosted the exhibition 'We the people, We the public space': recalling the well-known United Nations' campaign 'We the people' for the Global Goals' launched in 2015, the exhibition was intended to stress the concept that people and public space, intended as the space for democracy, social justice and equity, are strongly intertwined, so that talking about people is the same thing as talking about public space. The UN commitment 'Leaving no one behind'2 (United Nations, 2016 and 2017) for inclusive development is strictly related to people and therefore to public space: it is a demand for country leaders to prioritise the needs of those most marginalised and disadvantaged, facing poverty and discrimination, so that the goals for sustainable development are delivered by $2030^{3}$.

\footnotetext{
I https://www.un.org/sustainabledevelopment/blog/2015/09/we-the-people-for-the-global-goals/

2 https://unstats.un.org/sdgs/report/2016/leaving-no-one-behind

3 https://action4sd.org/leavenoonebehind/
} 
City Space Architecture is fully committed in promoting public space culture: since its foundation in 2013 the main objective of our organization was to inform, educate and spread awareness on the importance of public space in cities. Through high level academic events, art projects, workshops and internship programmes for high school, undergraduate, master and $\mathrm{PhD}$ students, online campaigns and community-based projects, engaging researchers, scholars, professionals, policy makers, artists, activists, NGOs and Universities, in less than five years, with a tireless, motivated and persistent attitude, we brought the message on public space at the highest levels and today we are proud partners of the UN-Habitat's Global Public Space Programme.

But what does it mean to promote public space culture? It means to include public space in the contemporary culture of cities and in the urban vision leading to sustainable and inclusive development. It means that public space is crucial if we really want to leave no one behind. So City Space Architecture's main commitment is aimed at putting public space at the centre of the current discourse on the future of cities and the future of humanity. But we need people to understand its value so that they can reclaim it as a fundamental human right for civil coexistence. And this is what we did at the Ninth session of the World Urban Forum, we showed the value of public space.

We divided the exhibition space in three sections. The first section was dedicated to 'We the people': we asked to our members, friends and supporters affiliated to our global network, to become our testimonials and be part of our exhibition by giving us a picture of their face (headshot), their first name and a very short statement on the importance of public space, from their perspective. The statement was intended to be linked to City Space Architecture's global campaign 'Stand up for Public Space!'4 which asks people to take a photo of their favourite public space and share it through their Twitter or Instagram personal profile, by using the hashtag \#standupforpublicspace and/or

\#myfavouritepublicspace. So we also asked to our members, friends and supporters to share with us a picture of their favourite public space, to be included in the second section of the exhibition 'We the public space'.

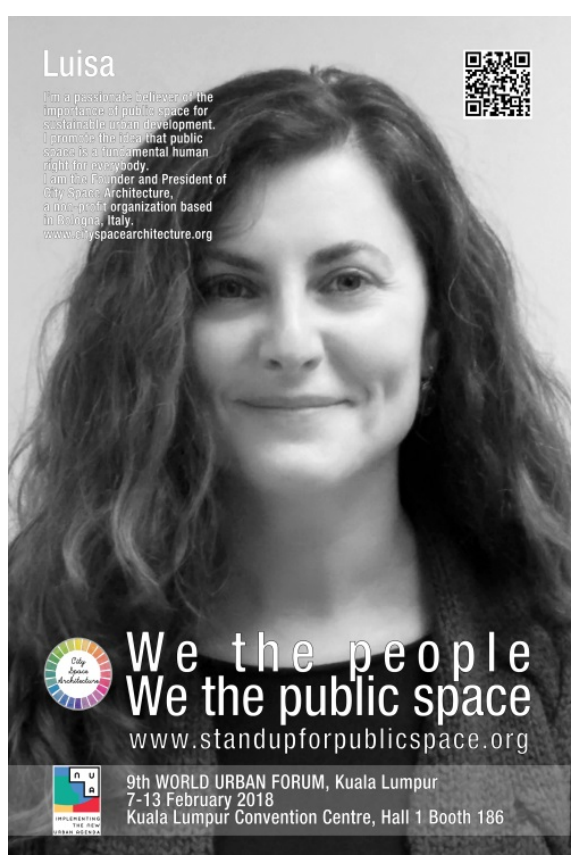

Fig. I. Face and statement by Luisa Bravo for City Space Architecture's exhibition 'We the people, We the public space' at the $9^{\text {th }}$ World Urban Forum in Kuala Lumpur (February 2018).

Statement: l'm a passionate believer of the importance of public space for sustainable urban development. I promote the idea that public space is a fundamental human right for everybody. I am the Founder and President of City Space Architecture, a non-profit organization based in Bologna, Italy.

\footnotetext{
${ }^{4}$ http://www.standupforpublicspace.org/
}

I54 | The Journal of Public Space, 3(I), 20I8 | ISSN 2206-9658

City Space Architecture / Queensland University of Technology / UN-Habitat 


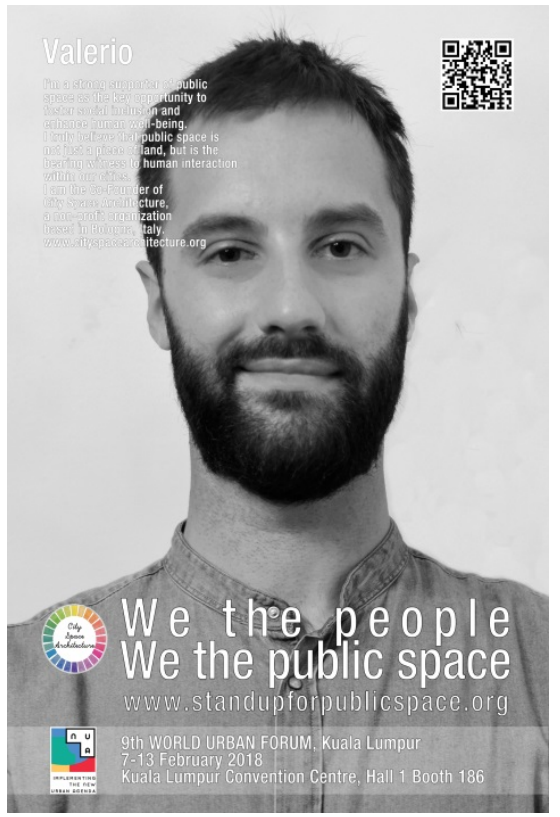

Fig. 2. Face and statement by Valerio Francia for City Space Architecture's exhibition 'We the people, We the public space' at the $9^{\text {th }}$ World Urban Forum in Kuala Lumpur (February 2018).

Statement: I'm a strong supporter of public space as the key opportunity to foster social inclusion and enhance human wellbeing. I truly believe that public space is not just a piece of land, but is the bearing witness to human interaction within our cities. I am the Co-Founder of City Space Architecture, a non-profit organization based in Bologna, Italy.

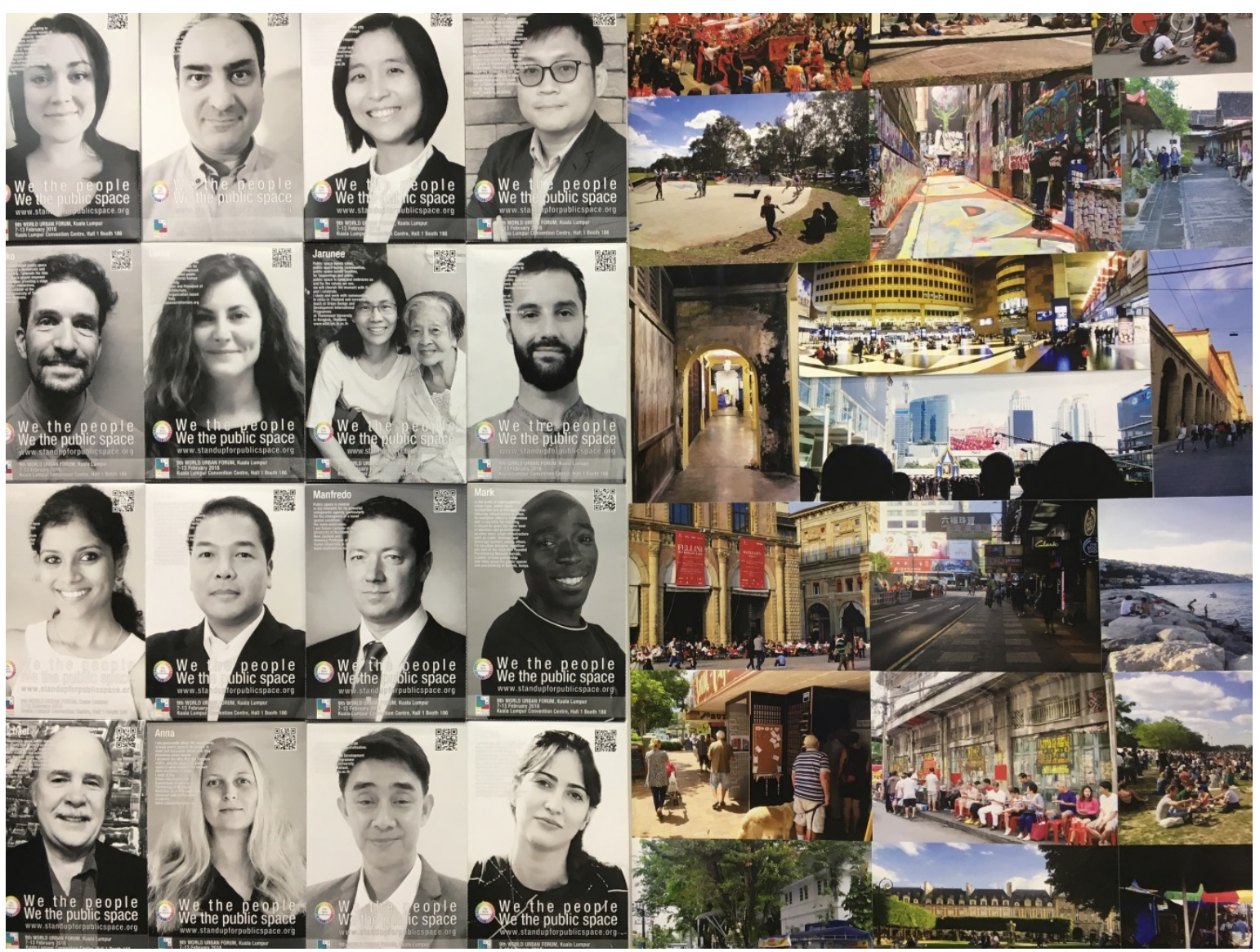

Fig. 3. City Space Architecture's exhibition 'We the people, We the public space' at the $9^{\text {th }}$ World Urban Forum in Kuala Lumpur (February 2018. A portion of the wall hosting the first two sections of the exhibition.

We put the first and second section of the exhibition in the same wall (Fig. 3), so that the visitors could clearly understand our message: public space is made by the people, with the people, for the people. 
In the third section of the exhibition, on the opposite wall, we put the five covers of the first five published issues of "The Journal of Public Space" together with a selection of papers (only the first page) from those issues. This section was intended to highlight the contribution of "The Journal of Public Space" in fostering the global discussion by providing public knowledge, with free contents for readers and without fees for authors to publish (the fee is known as 'article processing charge'). The model that we use for the journal is the same functioning model of a real public space which is open and freely accessible to everyone.

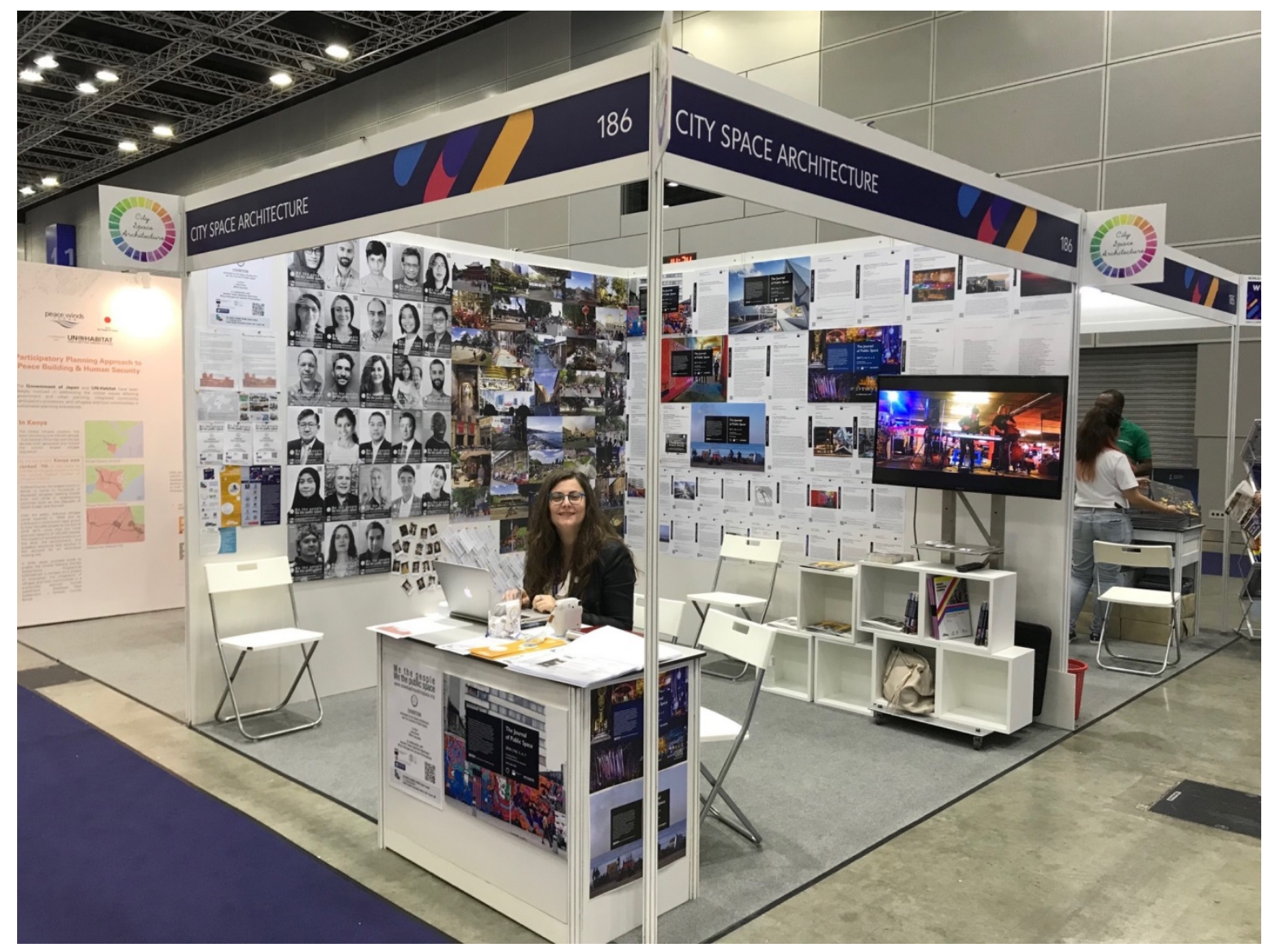

Fig. 4. Luisa Bravo, Founder and President of City Space Architecture, was the curator of the City Space Architecture's exhibition 'We the people, We the public space' at the $9^{\text {th }}$ World Urban Forum in Kuala Lumpur (February 2018).

In the exhibition space we also hosted a small library, to show City Space Architecture's four publications (a preview will be available on our ISSU channel in July $2018^{5}$ ). We also had a TV screen to show videos and power point presentations of our projects and of our partners' projects.

The exhibition was intended not just to show our work but mainly to engage people and to invite them to join the exhibition. We were looking for stories, perspectives, and reflections from everyone, of every age, race, ethnicity and gender, from any field and

\footnotetext{
${ }^{5}$ The four publications are: I) Pop-up City. Searching for instant urbanity, 2) MaPS. Mastering public space. A collaborative research network on cities and urbanity, 3) Past Present and Future of Public Space, Vol. I (Bologna) and 4) Past Present and Future of Public Space, vol. 2 (Venice).
}

I56 | The Journal of Public Space, 3(I), 20I8 | ISSN 2206-9658

City Space Architecture / Queensland University of Technology / UN-Habitat 
background. Every time a visitor expressed the interest to join and interact with the exhibition, he/she was asked to do two simple things:

- allowing us to take a Polaroid picture of their face, that could be added to the faces of the testimonials on the wall, together with their first name:

- completing the sentence "My favourite public space is..." by filling out a postcard.

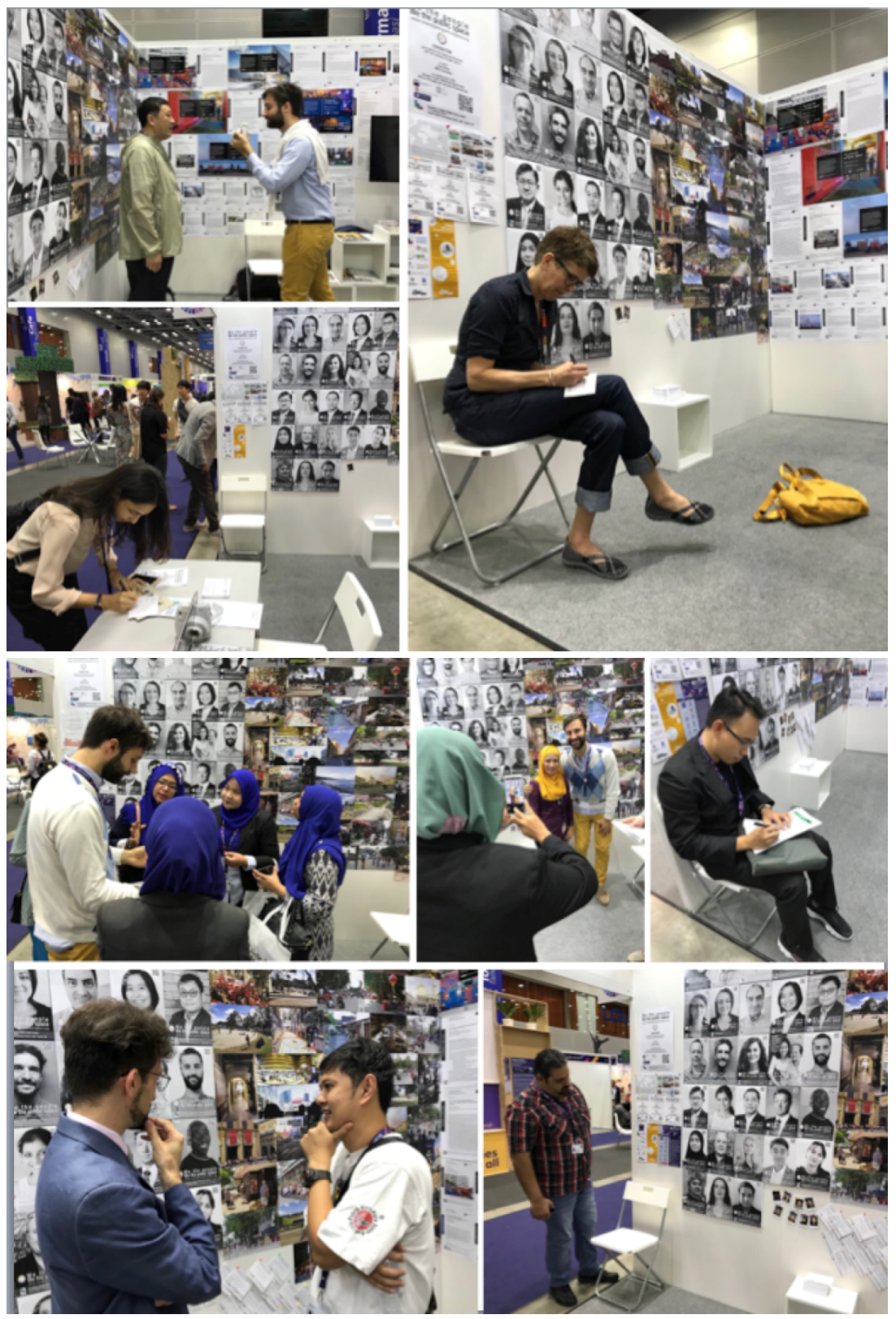

Fig. 5. Visitors interacting with the City Space Architecture's exhibition 'We the people, We the public space' at the $9^{\text {th }}$ World Urban Forum in Kuala Lumpur (February 2018).

While the picture was easy and fun to get, we realized that the sentence on the postcard was not an easy task for the visitors: many spent several minutes thinking about it and asked questions in order to properly understand what to write.

We then asked the visitor to pin both the postcard and the picture wherever he/she wanted on the wall. Quite easy steps, capable to create a strong connection between the 
visitor and the exhibition, so strong that many times the visitors wanted to freeze that moment through a picture, so that they could remember that experience and share it with family and friends ${ }^{6}$.

Also, the exhibition space became a real public space where visitors could freely come, sit and enjoy the atmosphere, reading The Journal of Public Space or our publications; it became also a meeting space for professional gatherings and social activities.
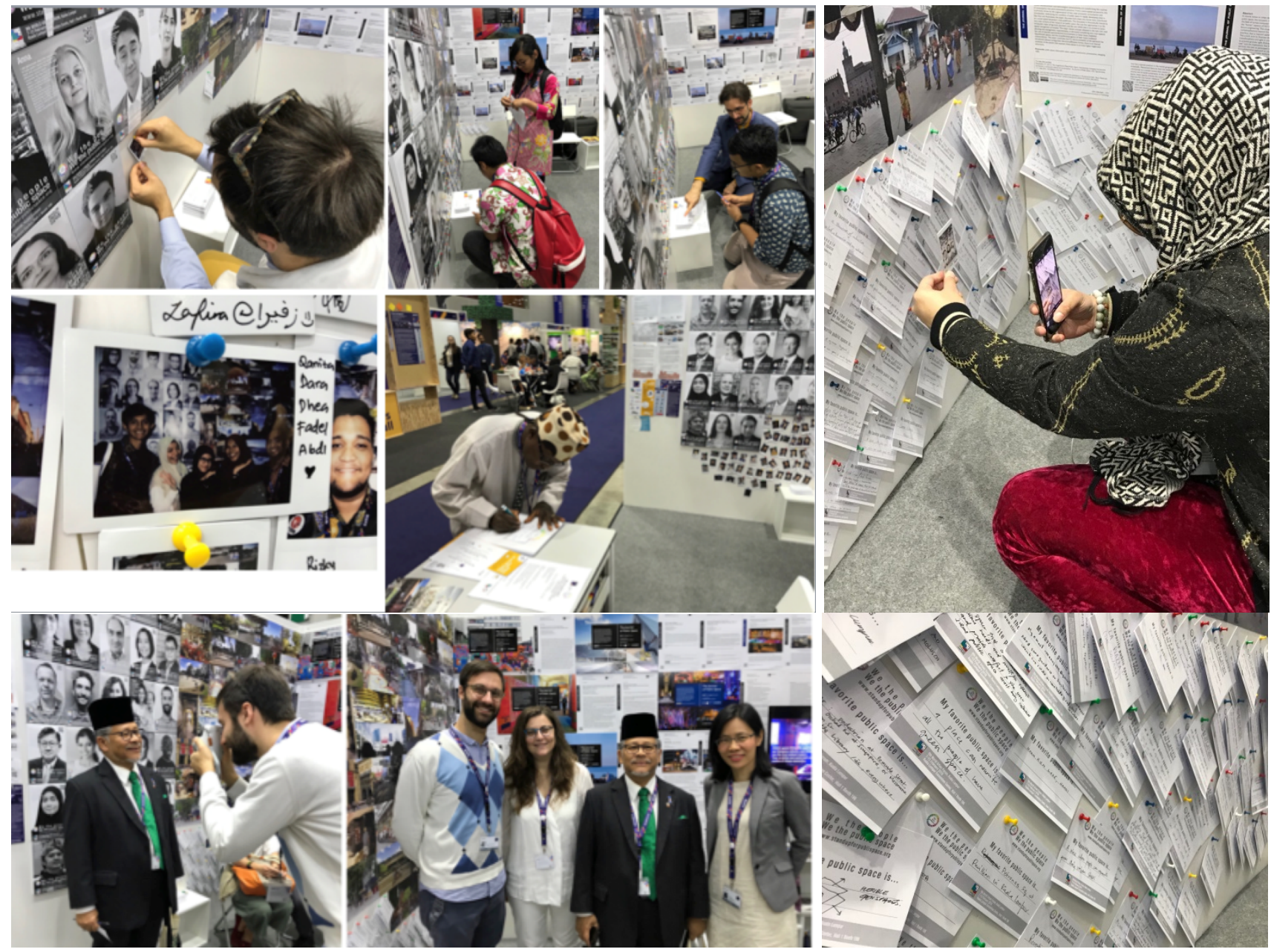

Fig. 6. Visitors interacting with the City Space Architecture's exhibition 'We the people, We the public space' at the $9^{\text {th }}$ World Urban Forum in Kuala Lumpur (February 2018).

Having so many visitors started to attract more visitors: people were curious to know about City Space Architecture, about the exhibition and about The Journal of Public Space. Since the space was really welcoming, as a very successful public space, some visitors stopped by to talk with us and share their vision and experience during the Ninth World Urban Forum, and their point of view on public space. Some other visitors brought joyfulness and playfulness, and some even danced with us!

\footnotetext{
${ }^{6}$ All the pictures of City Space Architecture's exhibition 'We the people, We the public space' at the $9^{\text {th }}$ World Urban Forum in Kuala Lumpur will be available on the City Space Architecture's Flickr account in July 2018.
}

I58 | The Journal of Public Space, 3(I), 20I8 | ISSN 2206-9658

City Space Architecture / Queensland University of Technology / UN-Habitat 


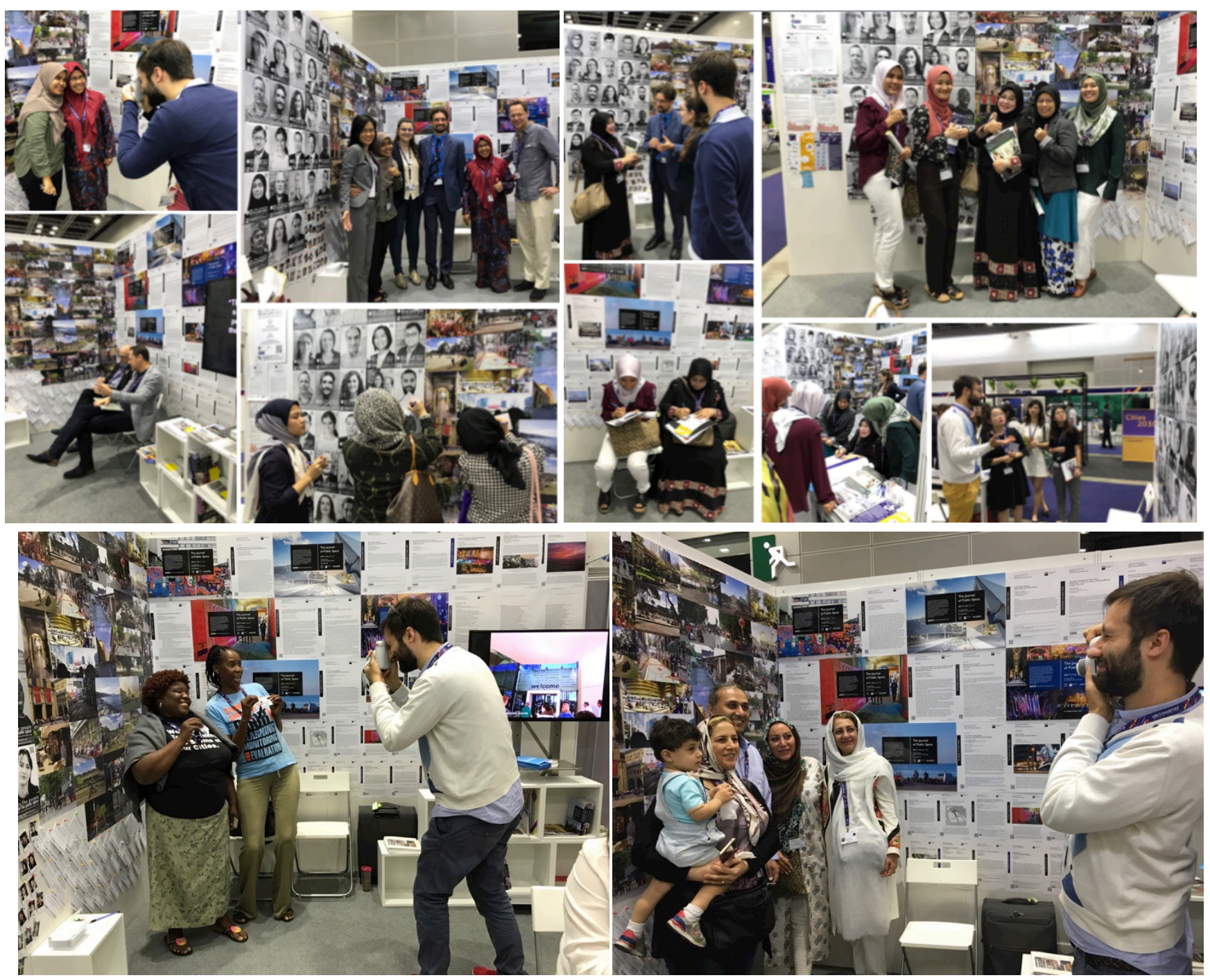

Fig. 7. Visitors interacting with the City Space Architecture's exhibition 'We the people, We the public space' at the $9^{\text {th }}$ World Urban Forum in Kuala Lumpur (February 2018).

We collected 168 postcards and 85 Polaroid pictures (most of them are individual pictures but some are group pictures or family pictures). We received mainly three kinds of answer:

I) some visitors decided to finish the statement by writing their favourite public space as squares, parks, streets, bus stops. All those places have a specific emotional value for them. So they finished the sentence "My favourite public space is..." with:

“... a bus stop. I've written lots of songs there”- Cornelia

“... in front of my house. Playground :) I love to see kids, young \& adults together in one place"-Mohammad

"... Time Square in NY, USA | There is everything and nothing it is non place | you can be and feel lost | you can meet everybody there." - Mizia 
2) some visitors decided to state a generic place as their favourite public space. It took several minutes to them to decide what to write, since they wanted to write down a concept easily comprehensible and shareable.

“... a full of green areas, without traffic jam anymore” - Khalid

“...under bridges and highways" - Ahmad

"... a road without cars but full of people instead. A narrow road surrounded by coloured and iconic buildings representing the culture and history of the place" - Lorenzo

3) some visitors decided to describe their ideal favourite public space: they wrote what a public space should look like, referring to meaning and purposes. Some thoughts are addressing social justice and personal desires towards a more open and inclusive community.

"...promoting city with local wisdom - the space that allows one to express myself, be myself \& connect with people, culture \& value "without border" - Nor

“... a place that has trees, with pop-up places of activities, where people can interact in the environment without rules and restrictions. A place where everything is possible" - Daniella

“... all girls and women and youth can assess not matter social norm, religious or regulars migrants or poor" - Mrs. Pham
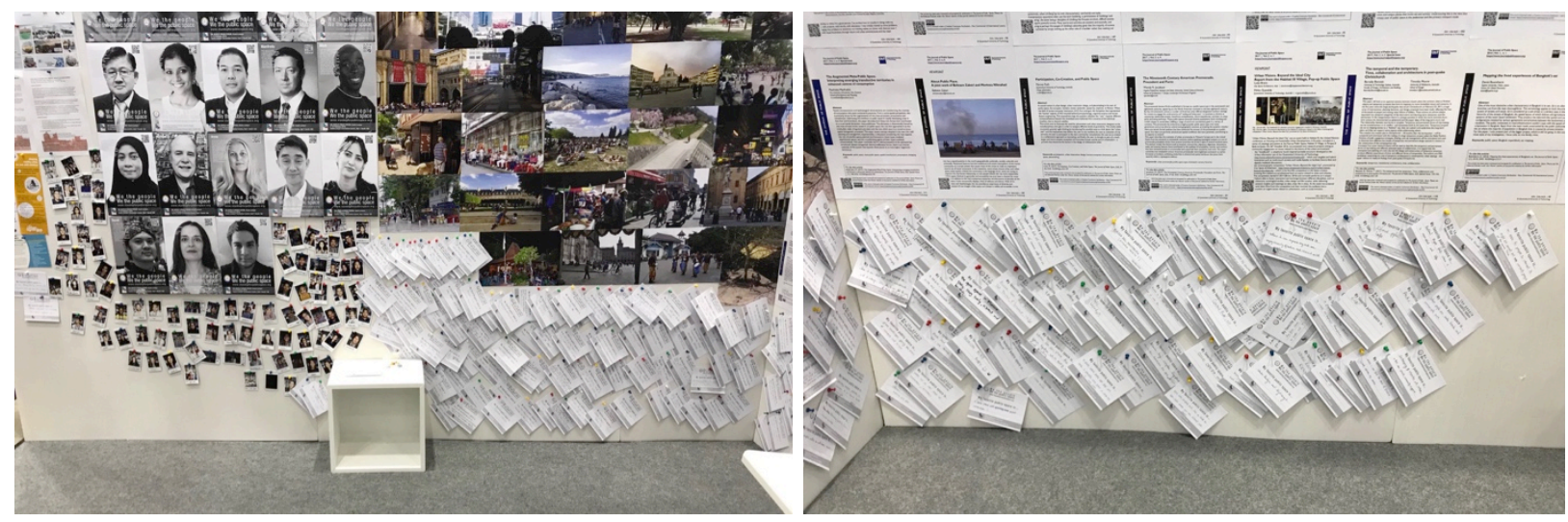

Fig. 8. Polaroid pictures and postcards from the visitors of the City Space Architecture's exhibition 'We the people, We the public space' at the $9^{\text {th }}$ World Urban Forum in Kuala Lumpur (February 2018).

Every answer is unique and it is related to a personal story, it is the result of a culture and it broadcasts a specific wish on how public space should be and should work. This is the reason why the concept of public space itself should be never taken for granted, especially if we say that we want to design and build cities for all.

"...the place that holds all the qualities of the true social inclusion, liveliness and joy.

Togetherness in the world" - Anna

I60 | The Journal of Public Space, 3(I), 20I8 | ISSN 2206-9658

City Space Architecture / Queensland University of Technology / UN-Habitat 
“...my school because when I see my students, I see bright future” - Amirah

“...a place where people can freely express their activism towards community engagement! - Shariman

“...a park, where I can connect with my childhood experiences.” - Zailin

In addition, the curator Luisa Bravo invited and interviewed in our exhibition space major stakeholders attending the $9^{\text {th }}$ World Urban Forum, such as academic scholars, professionals from the public and private sectors, representatives from NGOs, Governmental Authorities and UN-Habitat. We recorded 29 short interviews, introduced by the curator Luisa Bravo, which will be available on City Space Architecture's YouTube channel ${ }^{7}$ in July $2018^{8}$.
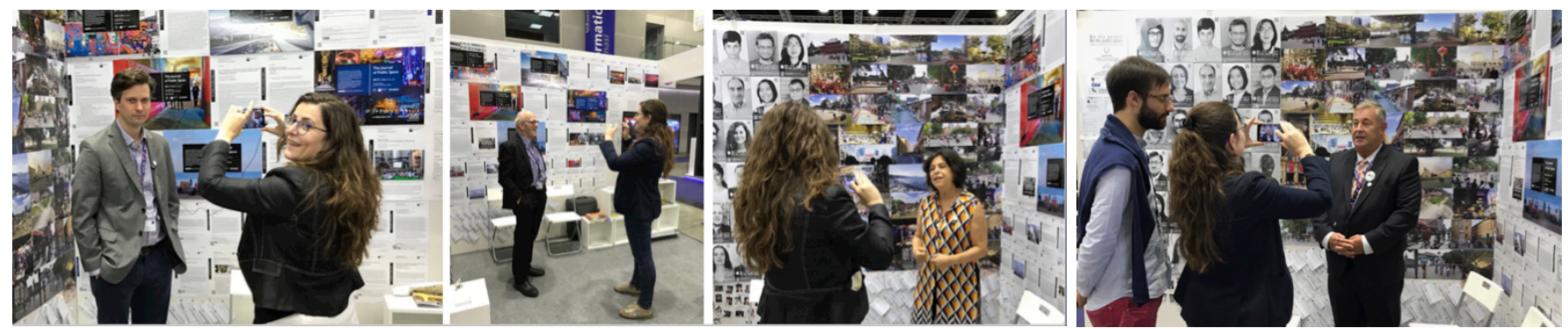

Fig. 8. Our curator Luisa Bravo interviewing major stakeholders at the City Space Architecture's exhibition 'We the people, We the public space' at the 9th World Urban Forum in Kuala Lumpur (February 2018).

At the end of seven fully busy and exciting days at the $9^{\text {th }}$ World Urban Forum in Kuala Lumpur, the response we received from all visitors who visited our exhibition space was overwhelming. Not just for the unexpected number of visitors that wanted to interact with our exhibition, mostly young people (students), every day throughout the day, but also for the gentle attitude towards us and the willingness to give their contribution and participate in the ongoing global discussion around public space. This was the most rewarding result that we achieved at the $9^{\text {th }}$ World Urban Forum: we understood once again that our future

\footnotetext{
${ }^{7}$ https://www.youtube.com/user/CitySpaceArchiTube

${ }^{8}$ Our curator Luisa Bravo interviewed: Anna Erlandson (artist, Sweden), Circe Gama Monteiro (Universidade Federal de Pernambuco, Brazil), Costanza Pera (Ministry of Infrastructure and Mobility, Italy), David Sagita (United Cities and Local Governments Asia Pacific, Indonesia), Ethan Kent (Project for Public Spaces, USA), Francesco Rossini (The Chinese University of Hong Kong, Hong Kong), Gini Lee (University of Melbourne, Australia), Greg Budworth (Compass Housing, Australia), Gregor Mews (Urban Synergies Group, Australia), Hendrik Tieben (The Chinese University of Hong Kong, Hong Kong), Jarunee Pimonsathean (Thammasat University, Thailand), Judith Hermanson (IHC Global, USA), Katherine Kline (General Assembly of Partners of the United Nations, USA), Kevin Hsu (Stanford University, USA), Lance Brown (Consortium for Sustainable Urbanization, USA), Laura Petrella (UN-Habitat, Kenya), Lorenzo Petrillo (LOPELAB, Singapore), Margorzata Hanzl (Lodz University of Technology, Poland), Margarita Greene (Pontificia Universidad Catolica de Chile, Chile), Michael Mehaffy (KTH Royal Institute of Technology, Sweden), Nor Hayati (University of Malaya, Malaysia), Pietro Garau (Institute of Urban Planners, Italy), Robert Wong (architect, Hong Kong), Setha Low (The Graduate Center City University of New York, USA), Simone D'Antonio (ANCI Association of Cities and Municipalities, Italy), Tarun Sharma (Nagrika, India), Teresa Boccia (University of Naples Federico II, Italy), Thozamile Botha (Housing Development Agency, South Africa), Vincent Kitio (UNHabitat, Kenya).
} 
is about people, that our future is about public space. And this is a strong encouragement to continue our mission at the global level.

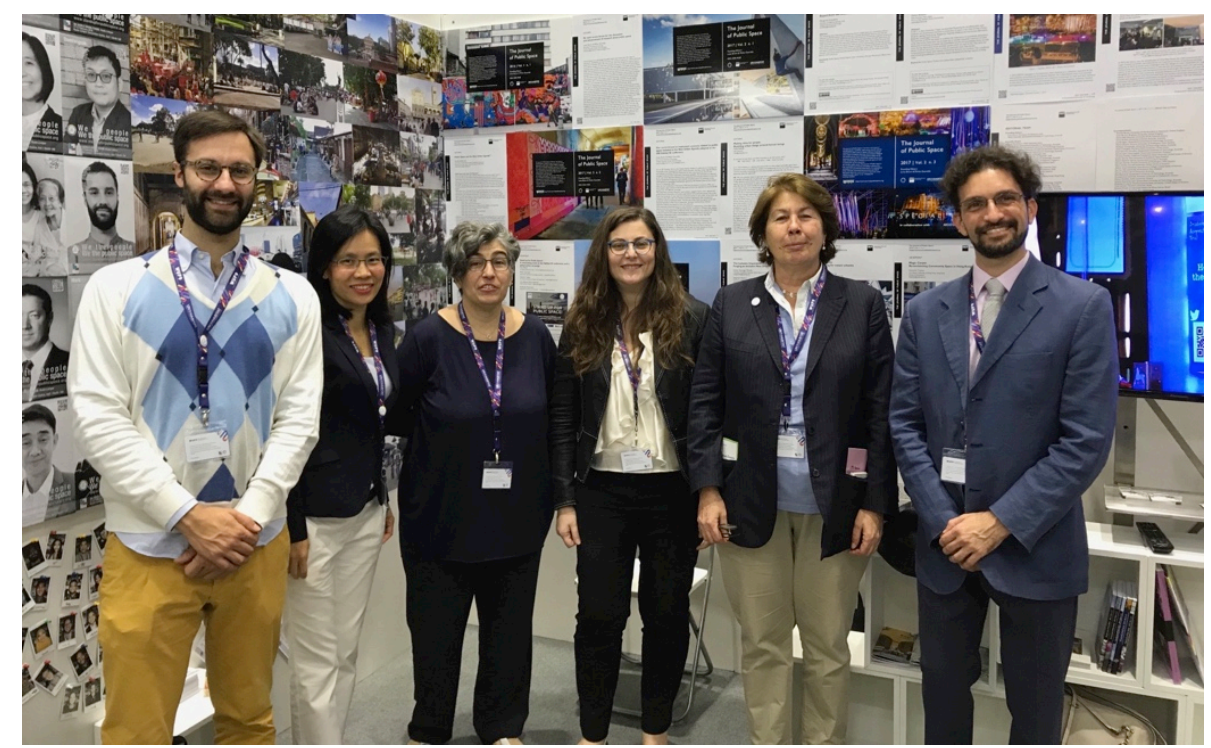

Fig. 9. Special guests at the City Space Architecture's exhibition 'We the people, We the public space' at the 9th World Urban Forum in Kuala Lumpur (February 2018). From left to right: Valerio Francia (City Space Architecture, Italy), Jarunee Pimonsathean (Thammasat University, Thailand), Laura Petrella (UN-Habitat, Kenya),

Luisa Bravo (City Space Architecture, Italy), Costanza Pera (Ministry of Infrastructure and Mobility, Italy), Mirko Guaralda (Queensland University of Technology, Australia).

\section{References}

Bravo, L., Guaralda, M., Tieben, H., Saltos Espinoza, L. and Manfredini, M. (20I7) "Stand up for Public Space! A networking event at the Habitat III conference and a global online campaign", The Journal of Public Space, 2(I), pp. I63-I66. doi: 10.5204/jps.v2il.6I.

United Nations Department of Social and Economic Affairs (2016), Leaving no one behind: the imperative of inclusive development, Report on the World Social Situation 2016, Executive Summary, available at http://www.un.org/esa/socdev/rwss/2016/executive-summary.pdf United Nations (2017) Leaving No One Behind: Equality and Non-Discrimination at the Heart of Sustainable Development. A Shared United Nations System Framework for Action, available at https://www.unsceb.org/CEBPublicFiles/CEB\%20equality\%20framework-A4-web-rev3.pdf

\section{To cite this article:}

Bravo, L. and Francia, V. (2018). We the people, We the public space. An interactive exhibition at the 9th World Urban Forum. The Journal of Public Space, 3(I), I53-162. DOI: 10.5204/jps.v3iI.325

This article has been accepted for publication in The Journal of Public Space. Please see the Editorial Policies under the 'About' section of the journal website for further information.

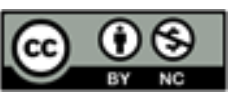

This work is licensed under a Creative Commons Attribution - Non Commercial 4.0 International License - https://creativecommons.org/licenses/by-nc/4.0/

162 | The Journal of Public Space, 3(I), 2018 | ISSN 2206-9658

City Space Architecture / Queensland University of Technology / UN-Habitat 